JMPF Vol. 9 No. $4: 225-237$

ISSN-p : 2088-8139

ISSN-e : 2443-2946

DOI : $10.22146 / j m p f .38869$

\title{
Profil Kerapuhan dan Masalah Terkait Obat pada Kelompok Lanjut Usia di Panti Jompo Kota Surabaya
}

\author{
The Profile of Frailty and Drug Related Problems Among Nursing Homes-dwelling Elderly People \\ in Surabaya
}

\author{
Verlita Evelyn Susanto ${ }^{1}$, Adji Prayitno Setiadi ${ }^{1,2^{*}}$, Bobby Presley ${ }^{1,2}$, Steven Victoria Halim ${ }^{1,2}$, Eko \\ Setiawan ${ }^{1,2}$ \\ 1. Departemen Farmasi Klinis dan Komunitas, Fakultas Farmasi, Universitas Surabaya \\ 2. Pusat Informasi Obat dan Layanan Kefarmasian (PIOLK), Fakultas Farmasi, Universitas Surabaya \\ Submitted: 17-09-2018 Revised: 24-06-2019 Accepted: 30-12-2019 \\ Korespondensi : Adji Prayitno Setiadi : Email : adji_ps@hotmail.com
}

\begin{abstract}
ABSTRAK
Kondisi klinis yang semakin rapuh dan masalah terkait penggunaan obat (MTO) cukup sering dijumpai pada kelompok lanjut usia (lansia) yang tinggal di panti jompo. Sampai saat ini, belum banyak terdapat informasi terkait kondisi kerapuhan dan MTO pada lansia yang tinggal di panti jompo di Indonesia. Tujuan penelitian ini adalah untuk menggambarkan profil kerapuhan dan MTO pada lansia yang tinggal di panti jompo kota Surabaya. Penelitian ini merupakan penelitian potong lintang yang dilakukan pada 3 (tiga) panti jompo di kota Surabaya. Kuesioner Integrated Systematic Care for older People (ISCOPE) digunakan untuk mengidentifikasi profil kerapuhan partisipan penelitian. Beers Criteria, screening tool of older person's prescriptions (STOPP), geriatric dosage handbook dan drug interactions analysis and management digunakan untuk identifikasi dan analisis MTO pada penelitian ini. Beberapa MTO yang dianalisis dalam penelitian ini adalah ketidaktepatan pemilihan obat, interaksi obat, dan ketidaktepatan dosis. Total terdapat 68 orang lansia yang dilibatkan dalam penelitian ini dan sebanyak 41,18\% diklasifikasikan sebagai lansia rapuh. Pada penelitian ini tidak ditemukan adanya interaksi obat yang bermakna klinis, namun demikian secara berturut-turut sebanyak 58,82\% dan 19,12\% lansia menggunakan dosis obat yang tidak tepat dan menggunakan obat yang sebaiknya dihindari. Temuan terkait kondisi kerapuhan dan MTO pada lansia mengindikasikan perlunya strategi dan intervensi berkesinambungan yang tepat untuk mengoptimalkan penggunaan obat pada lansia yang tinggal di panti jompo.
\end{abstract}

Kata kunci: lanjut usia; kerapuhan; masalah terkait penggunaan obat

\section{ABSTRACT}

Frailty and drug related problems (DRPs) are common among elderly who lives in the nursing home. There is currently limited information available regarding the profile of frailty and DRPs among elderly living in the nursing homes in Indonesia. This project aims to describe the profile of frailty and DRPs among nursing home residents in Surabaya. This cross-sectional study was conducted in three nursing homes in Surabaya. Integrated Systematic Care for older People (ISCOPE) questionnaire was used to identify the frailty profile among participants. Beers Criteria, screening tool of older person's prescriptions (STOPP), geriatric dosage handbook and drug interactions analysis and management were used as tools to identify and analyse drug related problems in this study. Several DRPs were identified in this study including inappropriate drug choices, drugs interaction, and inappropriate dose of drugs. In total, 68 elderly were recruited in this study and $41.18 \%$ of them were classified as frail older people. There was no drugs interaction with "clinical significance" being identified, however, inappropriate dose of drugs and potentially inappropriate drug choices were found in $58.82 \%$ and $19.12 \%$ of nursing home residents, respectively. Findings regarding the profile of frailty and DRPs among elderly may indicate the needs to implement an appropriate intervention strategic in order to optimize the use of medications among nursing homes-dwelling elderly people.

Keywords: elderly; frailty; drug related problem

\section{PENDAHULUAN}

Jumlah populasi lanjut usia (lansia) secara global mengalami peningkatan selama beberapa dekade terakhir.1,2 Pada tahun 2017, jumlah penduduk dengan usia $\geq 60$ tahun di seluruh dunia berjumlah 962 juta dan jumlah 
tersebut mengalami peningkatan dua kali lipat dibandingkan tahun 1980. ${ }^{\text {Sebanyak dua-per- }}$ tiga dari total lansia di dunia berada di negara berkembang. ${ }^{1}$ Di Indonesia, sebanyak 9,03\% dari total penduduk pada tahun 2017 berusia $\geq 60$ tahun dan Jawa Timur merupakan salah satu dari tiga provinsi dengan persentase penduduk lansia terbanyak di Indonesia $(12,25 \%) .^{3}$ Kota Surabaya merupakan salah satu wilayah di provinsi Jawa Timur dengan tingkat kepadatan penduduk yang tinggi dan sebanyak 8,23\% dari total penduduk kota Surabaya adalah kelompok lansia. ${ }^{4}$ Berdasarkan status tempat tinggal, sebagian besar lansia $(87,60 \%)$ di Indonesia tinggal bersama dengan pasangan atau keluarga dan hanya 9,66\% lansia yang tinggal sendiri. ${ }^{5}$ Salah satu fenomena yang saat ini banyak diamati secara khusus di kota besar adalah peningkatan jumlah lansia yang tinggal di panti sosial lanjut usia yang disebabkan oleh berbagai macam latar belakang. Sebagai contoh, jumlah lansia yang tinggal di Panti Sosial Tresna Werdha di Jawa Timur mengalami peningkatan dari 650 lansia pada tahun 2004 menjadi 872 pada tahun $2016 .^{6}$

Seiring dengan bertambahnya usia, permasalahan terkait kesehatan cenderung mengalami peningkatan. Kementerian Kesehatan Republik Indonesia (KemenKes RI) menyatakan bahwa angka kesakitan lansia di perkotaan dan perdesaan pada tahun 2015 secara berturut-turut adalah $26,89 \%$ dan $30,14 \%$. Dibandingkan dengan data tahun 2013 maupun 2014, angka kesakitan lansia baik di perkotaan maupun pedesaan pada tahun 2015 mengalami peningkatan berkisar 3-4\%. ${ }^{3}$ Sakit yang dialami lansia dapat berupa sakit akut (seperti pilek, batuk, dan demam) maupun kronis. ${ }^{5}$ Penggunaan obat merupakan salah satu cara untuk menangani gangguan kesehatan, termasuk pada lansia. Macam obat yang digunakan lansia dapat dipengaruhi oleh macam gangguan sakit dan tingkat keparahan kondisi sakit. Semakin banyak macam diagnosis atau semakin parah tingkat sakit seorang pasien, pada umumnya, macam obat yang digunakan juga meningkat. Beberapa bukti penelitian menunjukkan bahwa rata-rata macam obat yang digunakan oleh lansia berkisar antara 7-13.7-10

Peningkatan macam obat yang digunakan, termasuk oleh lansia, dapat meningkatkan risiko terjadinya masalah terkait penggunaan obat/MTO (drug-related problems; DRP). Dalam sebuah penelitian yang dilakukan terhadap 2.465 lansia di 41 panti jompo, Fog et al., (2017) menyatakan sebanyak $82,70 \%$ dari total pasien mengalami MTO dengan rata-rata $3 \mathrm{MTO} /$ lansia. ${ }^{11}$ Jenis MTO terbanyak yang ditemukan dalam penelitian tersebut adalah penggunaan obat yang tidak diperlukan (unnecessary drugs), penggunaan dosis obat yang berlebih (excess dosing), kebutuhan akan pemantauan obat yang tidak dilakukan (lack of monitoring drug use), pemilihan obat yang tidak tepat (inappropriate drug choice), kebutuhan akan penambahan obat baru (need for additional drugs). ${ }^{11}$ Permasalahan terkait unnecessary drugs, inappropriate drug choice, need for additional drugs merupakan bagian dari sebuah domain MTO yakni permasalahan terkait pemilihan obat (drug choice problem). Dalam penelitian multi-centers yang dilakukan oleh Fog et al., (2017) tersebut dapat disimpulkan bahwa domain masalah terkait pemilihan obat merupakan salah satu permasalahan utama lansia yang tinggal di panti jompo. ${ }^{11}$ Penelitian lain yang dilakukan dengan ruang lingkup yang lebih luas, yakni menggunakan basis data (database) nasional di Norwegia terhadap 11.491.065 resep untuk lansia, menunjukkan sebanyak 34,80\% lansia mendapatkan terapi yang sebaiknya dihindari pada lansia (potentially inappropriate medication). ${ }^{12}$ Hasil penelitian tersebut semakin mengindikasikan permasalahan terkait pemilihan obat pada lansia yang perlu diantisipasi. Hasil sebuah kajian sistematis pada 52 penelitian yang dilakukan di Eropa semakin menegaskan bahwa permasalahan terkait pemilihan obat pada lansia merupakan permasalahan yang nyata dihadapi tenaga kesehatan di berbagai negara. Prevalensi penggunaan obat yang seharusnya dihindari untuk lansia, dalam hal ini dinyatakan sebagai potentially inappropriate prescribing, di berbagai negara Eropa adalah 
22,60\%. ${ }^{13}$ Ketidaktepatan penggunaan obat pada lansia dapat meningkatkan risiko terjadinya reaksi obat yang tidak dikehendaki/ROTD (adverse drugs reaction; ADR), penurunan kualitas hidup pasien, peningkatan kebutuhan untuk penanganan di instalasi gawat darurat (IGD). ${ }^{14,15}$ Dengan mempertimbangkan risiko yang ditimbulkan akibat ketidaktepatan pemilihan obat, terdapat beberapa pedoman yang dapat digunakan untuk memilih obat yang tepat pada lansia, antara lain: Screening tool of older person's prescriptions and screening tool to alert doctors to right treatment (STOPP and START) ${ }^{16}$ dan Beers Criteria. ${ }^{17}$

Tingkat kerapuhan lansia (frailty) merupakan salah satu faktor yang mempengaruhi ketepatan penggunaan obat pada lansia. ${ }^{18,19}$ Frailty dapat diartikan sebagai penurunan kondisi klinis dari lansia yang disebabkan oleh penurunan fungsi fisiologis dari beberapa organ sehingga berdampak pada penurunan kemampuan untuk menghadapi situasi yang penuh dengan tekanan, baik berupa aktivitas sehari-hari yang seharusnya dapat dilakukan (contoh: menyapu lantai, memasak) atau "tekanan" yang bersifat akut (contoh: kondisi sakit). ${ }^{20}$ Semakin besar penurunan fungsi fisiologis organ, atau dengan kata lain semakin rapuh (frail), menyebabkan semakin terbatasnya pilihan terapi obat yang dapat digunakan secara efektif dan aman pada kelompok tersebut. Sebuah penelitian retrospektif pada 931 lansia dengan setting komunitas di negara Irlandia membuktikan bahwa terjadinya $\geq 2$ permasalahan terkait pemilihan obat (drug choice problem) ditemukan dua kali lipat lebih banyak pada lansia rapuh. ${ }^{16}$ Penelitian lain oleh Cullinan et al., (2016) menemukan bahwa permasalahan terkait pemilihan obat terjadi sebanyak dua kali lipat lebih banyak pada pasien lansia yang memiliki nilai angka kerapuhan (frailty index) melebihi batas yang telah ditentukan dalam penelitian tersebut. ${ }^{19}$ Alat yang dapat digunakan untuk mengidentifkasi kerapuhan, umumnya berupa kuesioner, sangat bervariasi dan setiap alat ukur memiliki kriteria dan nilai batas yang berbeda untuk mengklasifikasikan kerapuhan. ${ }^{21,22}$

Sampai saat ini, penelitian terkait ketepatan penggunaan obat pada lansia di panti jompo di Indonesia dengan menggunakan pedoman atau tools yang didesain spesifik untuk lansia belum banyak dilakukan. Selain itu, bukti penelitian terkait gambaran umum tingkat kerapuhan lansia dan jenis MTO yang dialami oleh lansia di panti jompo dengan setting Indonesia, khususnya kota Surabaya, juga belum banyak ditemukan. Tujuan dari penelitian ini adalah untuk menggambarkan profil kerapuhan dan jenis MTO yang terjadi pada lansia yang tinggal di panti jompo kota Surabaya.

\section{METODE}

Penelitian ini merupakan penelitian observasional dengan desain potong lintang (cross sectional) yang dilakukan secara prospektif pada beberapa panti jompo yang terdaftar di Dinas Sosial Kota Surabaya. Proses perijinan untuk melaksanakan penelitian didapatkan dari pengelola panti jompo sebagaimana disarankan oleh Badan Kesatuan Bangsa dan Politik dan Perlindungan Masyarakat (Bakesbangpol dan Linmas) dengan mempertimbangkan status kepemilikan panti jompo. Pengambilan sampel dilakukan dengan metode purposive sampling. Sampel dalam penelitian ini adalah lansia yang tinggal di panti jompo terdaftar, berusia $\geq 60$ tahun, dan setuju untuk mengikuti penelitian. Persetujuan keterlibatan dalam penelitian ini didapatkan melalui verbal consent. Lansia yang tidak menggunakan obat pada saat kunjungan, lansia yang tuli atau tidak bisa bicara, serta lansia yang menderita gangguan mental (termasuk pikun) tidak dilibatkan dalam penelitian ini. Proses identifikasi gangguan mental, khususnya pikun, dilakukan dengan menanyakan kepada petugas panti jompo. Seluruh lansia pada panti jompo yang memberikan ijin pelaksanaan penelitian dilibatkan dalam penelitian ini. Aspek etis dari penelitian ini 
telah dikaji dan disetujui oleh Institutional Ethical Committee University of Surabaya (No: 068/KE/II/2019).

Data karakteristik lansia (meliputi: jenis kelamin, usia, asal tempat tinggal, kerapuhan lansia, jenis penyakit, kombinasi penyakit lansia, penanggung biaya pengobatan, kemandirian pengelolaan obat) didapatkan dengan cara bertanya secara langsung kepada lansia dan/atau petugas panti jompo yang dapat ditemui pada saat pengambilan data. Usia lansia pada penelitian ini dikelompokkan menjadi tiga, yakni: lansia (60-74 tahun), lansia tua (75-90 tahun), dan lansia sangat tua ( $>90$ tahun). Proses identifikasi kerapuhan lansia dilakukan dengan menggunakan kuesioner Integrated Systematic Care for older People (ISCOPE). ${ }^{23}$ Total terdapat empat domain yang diukur dalam kuesioner tersebut, yaitu: 1) kemampuan melakukan aktivitas seharihari (6 pertanyaan), 2) kesehatan (7 pertanyaan), 3) psikologis (4 pertanyaan), 4) fungsi sosial (4 pertanyaan). Jawaban positif terhadap minimum dua pertanyaan dalam satu domain akan mendapat nilai satu (1). ${ }^{24}$ Dengan demikian, nilai maksimum yang dapat diukur dengan menggunakan kuesioner tersebut adalah 4 (empat) dan lansia dinyatakan rapuh apabila mendapatkan skor sebanyak $\geq 3$. Proses translasi kuesioner ISCOPE dilakukan melalui tiga tahap, yaitu: 1) forward translation oleh dua peneliti (VES dan ES), 2) backward translation oleh seorang warga negara asing yang mahir berbahasa Indonesia, 3) pre-testing terhadap 10 orang lansia. Modifikasi istilah dalam kuesioner juga dilakukan sebagai upaya untuk menyesuaikan dengan konteks budaya Indonesia. Uji validasi rupa dilakukan pada seorang expert dalam ilmu kesehatan masyarakat (APS) dan beberapa orang lansia (10 orang). Uji reliabilitas dilakukan dengan melihat internal consistency kuesioner yang ditentukan dengan menggunakan nilai Cronbach's alpha.

Data karakteristik obat (meliputi: jenis obat dan jumlah kombinasi obat) diidentifikasi dengan cara meminta lansia atau petugas panti jompo untuk menunjukkan obat atau daftar obat yang digunakan pada saat proses pengambilan data. Proses klarifikasi dengan menanyakan "apakah terdapat obat lain selain yang ditunjukkan ini?" dilakukan untuk memastikan tidak terdapat penggunaan obat oleh lansia yang terlewatkan untuk diidentifikasi.

Beberapa MTO yang dianalisis dalam penelitian ini adalah ketidaktepatan pemilihan obat, interaksi obat, dan kesesuaian dosis. Ketidaktepatan pemilihan obat diidentifikasi dengan cara membandingkan obat yang secara aktual digunakan lansia dengan daftar yang terdapat pada Beers criteria $^{17}$ dan bagian STOPP dari STARTSTOPP criteria. ${ }^{16}$ Buku referensi Drug Interactions Analysis and Management (2013)25 dan Geriatric Dosage Handbook (2015) ${ }^{26}$ secara berturut-turut digunakan sebagai acuan utama untuk menganalisis interaksi obat dan ketepatan dosis obat. Interaksi obat yang dilaporkan dalam penelitian ini adalah interaksi obat yang bermakna klinis (interaksi kelas 1 dan 2) berdasarkan pustaka rujukan. ${ }^{26}$ Analisis interaksi hanya dilakukan untuk kombinasi obat yang digunakan secara bersamaan.

Seluruh data dalam penelitian ini dianalisis dengan menggunakan statistika deskriptif dengan menentukan nilai rata$\mathrm{rata} / \mathrm{mean}$ dan/atau dinyatakan dalam persentase. Uji korelasi hubungan antara kerapuhan dan jumlah MTO menggunakan Spearman's Rho (SPSS versi 23).

\section{HASIL DAN PEMBAHASAN}

Total terdapat 6 (enam) panti jompo yang terdapat dalam daftar Dinas Sosial Kota Surabaya dan 3 (tiga) dari antaranya memberikan ijin penelitian. Satu panti jompo tidak dilibatkan dalam penelitian karena lansia yang berada di panti jompo tersebut memiliki gangguan mental. Satu panti jompo tidak memberikan ijin dan satu panti jompo tidak memberikan kejelasan sampai tenggang waktu yang diberikan. Sebanyak 68 lansia dilibatkan dalam penelitian ini dengan ratarata usia 75,63 tahun dan mayoritas berjenis kelamin perempuan (72,06\%). Terdapat perubahan redaksi kalimat dalam kuesioner 
Tabel I. Karakteristik Lansia di 3 Panti Jompo Tempat Penelitian

\begin{tabular}{|c|c|c|c|}
\hline Karakteristik & Total (\%) & Panti Jompo Jenis A & Panti Jompo Jenis B \\
\hline \multicolumn{4}{|l|}{ Jenis Kelamin } \\
\hline Laki-laki & $19(27,94 \%)$ & $19(41,30 \%)$ & $0(0,00 \%)$ \\
\hline Perempuan & $49(72,06 \%)$ & $27(58,70 \%)$ & $22(100,00 \%)$ \\
\hline Total & $68(100,00 \%)$ & $46(100,00 \%)$ & $22(100,00 \%)$ \\
\hline \multicolumn{4}{|l|}{ Kelompok usia } \\
\hline Usia lanjut & $25(36,77 \%)$ & $17(36,96 \%)$ & $8(36,36 \%)$ \\
\hline Lansia tua & $41(60,29 \%)$ & $28(60,87 \%)$ & $13(59,09 \%)$ \\
\hline Lansia sangat tua & $2(2,94 \%)$ & $1(2,17 \%)$ & $1(4,55 \%)$ \\
\hline Total & $68(100,00 \%)$ & $46(100,00 \%)$ & $22(100,00 \%)$ \\
\hline \multicolumn{4}{|l|}{ Usia (satuan tahun) } \\
\hline Mean & 75,63 & 74,77 & 76,04 \\
\hline SD & 8,55 & 10,08 & 7,80 \\
\hline Minimal & 60 & 60 & 60 \\
\hline Maksimal & 99 & 99 & 93 \\
\hline \multicolumn{4}{|l|}{ Asal tempat tinggal } \\
\hline Surabaya & $36(52,94 \%)$ & $27(58,70 \%)$ & $9(40,90 \%)$ \\
\hline Luar Surabaya & $32(47,06 \%)$ & $19(41,30 \%)$ & $13(59,10 \%)$ \\
\hline Total & $68(100,00 \%)$ & $46(100,00 \%)$ & $22(100,00 \%)$ \\
\hline \multicolumn{4}{|l|}{ Kerapuhan } \\
\hline Rapuh & $28(41,18 \%)$ & $21(45,65 \%)$ & $7(31,82 \%)$ \\
\hline Tidak rapuh & $40(58,82 \%)$ & $25(54,35 \%)$ & $15(68,18 \%)$ \\
\hline Total & $68(100,00 \%)$ & $46(100,00 \%)$ & $22(100,00 \%)$ \\
\hline
\end{tabular}

Keterangan : Panti Jompo Jenis $\mathrm{A}=$ terdapat petugas (perawat resmi berjumlah 4 orang khusus untuk mengurus pengobatan lansia). Jumlah panti jompo jenis $A=1$ (satu); Panti Jompo Jenis $B=$ tidak terdapat petugas khusus yang mengurus pengobatan lansia atau terdapat petugas tetapi bukan termasuk perawat resmi. Jumlah panti jompo jenis $B=2$ (dua).

sebagaimana disarankan oleh expert dan lansia yang terlibat dalam proses face validity. Nilai Cronbach's alpha untuk kuesioner ISCOPE dalam Bahasa Indonesia adalah 0,931 yang mengindikasikan bahwa pertanyaanpertanyaan dalam kuesioner yang telah disadur tersebut memiliki tingkat konsistensi yang baik dalam memetakan domain yang ingin dilihat. Karakteristik lansia termasuk profil kerapuhan lansia dapat dilihat pada Tabel I.

Hasil dari penelitian ini mengungkapkan bahwa $28 \quad(41,18 \%)$ dari total lansia diklasifikasikan rapuh. Persentase tersebut tidak benar-benar dapat digunakan untuk menggambarkan besarnya profil kerapuhan pada lansia di komunitas secara keseluruhan (community-dwelling elderly people) walaupun panti jompo juga merupakan bagian dari komunitas (non-hospitalized elderly). Hal tersebut perlu ditekankan dengan mempertimbangkan terdapat lansia di komunitas (mayoritas tinggal di luar panti jompo) yang masih dapat bekerja, sedangkan sebagian besar lansia dalam penelitian ini tidak bekerja. Berdasarkan data Badan Pusat Statistik tahun 2014, terdapat $47,48 \%$ lansia di Indonesia yang masih bekerja. ${ }^{5}$ Ditinjau dari jenis pekerjaannya, secara berturut-turut sebanyak $74,10 \%$ dan $22,55 \%$ lansia bekerja sebagai tenaga usaha/jasa (blue collar worker) dan buruh/operator/pekerja kasar (grey collar worker). ${ }^{5}$ Dua kelompok pekerjaan tersebut membutuhkan fisik yang relatif kuat untuk dapat menyelesaikan tuntutan pekerjaan dengan baik atau dengan kata lain dapat dikatakan "tidak rapuh". Oleh karena itu, profil kerapuhan lansia secara lebih luas di 
Tabel II. Jumlah Jenis Obat yang Digunakan Lansia

\begin{tabular}{ccc}
\hline Jumlah obat & Jumlah lansia & Persentase (\%) \\
\hline 1 & 24 & 35,29 \\
2 & 15 & 22,06 \\
3 & 12 & 17,65 \\
4 & 10 & 14,71 \\
5 & 1 & 1,47 \\
6 & 4 & 5,88 \\
7 & 2 & 2,94 \\
Total & $\mathbf{6 8}$ & $\mathbf{1 0 0}$ \\
\hline
\end{tabular}

komunitas dapat berbeda dengan hasil penelitian ini. Hasil sebuah kajian sistematis pada bukti penelitian terpublikasi yang tidak terbatas pada setting panti jompo menunjukkan adanya variasi prevalensi kerapuhan pada lansia, yakni berkisar dari $3.9 \%$ - $51.4 \%{ }^{27}$ Sampai sejauh ini, belum terdapat penelitian yang bertujuan untuk meng-identifikasi profil kerapuhan pada lansia di komunitas Indonesia yang tidak hanya terbatas pada lansia yang tinggal di panti jompo.

Rata-rata penggunaan obat pada lansia di penelitian ini sebanyak 3-4 obat (tabel II). Mayoritas pasien $(64,71 \%)$ dalam penelitian ini menggunakan lebih dari satu (1) jenis obat. Hasil penelitian ini selaras dengan hasil penelitian yang dilakukan dengan setting panti jompo di beberapa negara lain. ${ }^{7-10} \mathrm{Jumlah}$ jenis obat, khususnya lebih dari lima (5) jenis, merupakan faktor yang meningkatkan risiko terjadinya MTO, termasuk pada lansia. ${ }^{28}$ Selain jumlah jenis obat, kelompok yang membutuhkan bantuan pengasuh (caregivers) juga memiliki risiko mengalami MTO. ${ }^{28}$ Sebanyak 32 lansia $(47,06 \%)$ dalam penelitian ini menyatakan kebutuhannya untuk ditolong oleh petugas panti jompo untuk mengelola penggunaan obat. Ironisnya, satu (1) panti jompo dalam penelitian ini tidak memiliki petugas khusus untuk membantu lansia menggunakan obatnya. Sangat dimungkinkan terdapat panti jompo lain di regional Jawa Timur yang tidak memiliki petugas untuk membantu mengelola penggunaan obat lansia sebagaimana ditemukan pada sebuah panti jompo dalam penelitian ini. Keterbatasan dana dan tenaga kerja mungkin menjadi salah satu pertimbangan pemilik atau pengelola sarana panti jompo, khususnya yang bersifat sosial, untuk tidak mempekerjakan petugas khusus. Oleh karena itu, perlu dipikirkan strategi dan intervensi untuk mengoptimalkan penggunaan obat pada lansia yang tinggal di panti jompo tanpa petugas khusus.

Jenis obat terbanyak yang digunakan oleh lansia dalam penelitian ini adalah amlodipin $(11,06 \%)$, simvastatin $(8,17 \%)$, allopurinol $(6,25 \%)$, metformin $(5,29 \%)$, vitamin B1 (5,29\%), vitamin B12 (5,29\%) (Tabel III). Profil penggunaan obat tersebut selaras dengan profil penyakit yang dinyatakan oleh pasien atau petugas panti jompo, yaitu: hipertensi, diabetes, stroke, dan asam urat secara berturut-turut yakni sebanyak $28,95 \%$, $15,79 \%$, 12,28\%, dan 12,28\% (Tabel IV). Pada dasarnya, prinsip terapi hipertensi dan diabetes mellitus pada lansia serupa dengan terapi pasien dewasa pada umumnya. 29,30 Salah satu hal yang menjadi perhatian khusus pemberian terapi obat untuk dua penyakit kronis tersebut pada lansia adalah pencegahan terjadinya hipotensi ortostatik dan hipoglikemia yang dapat meningkat-kan risiko jatuh (falls) pada lansia. ${ }^{31-34}$ Kejadian jatuh pada lansia menyebabkan peningkatan risiko perburukan kondisi kesehatan lansia dan beban biaya kesehatan. ${ }^{35,36}$ Oleh karena itu, ketepatan penggunaan obat yang meliputi tepat jenis, dosis, dan frekuensi pemberian, perlu dijaminkan pada lansia. Selain hal tersebut, proses pemantauan kondisi pasien, termasuk tekanan darah dan kadar gula darah, perlu dilakukan secara periodik 
Tabel III. Jenis Obat yang Digunakan oleh Lansia

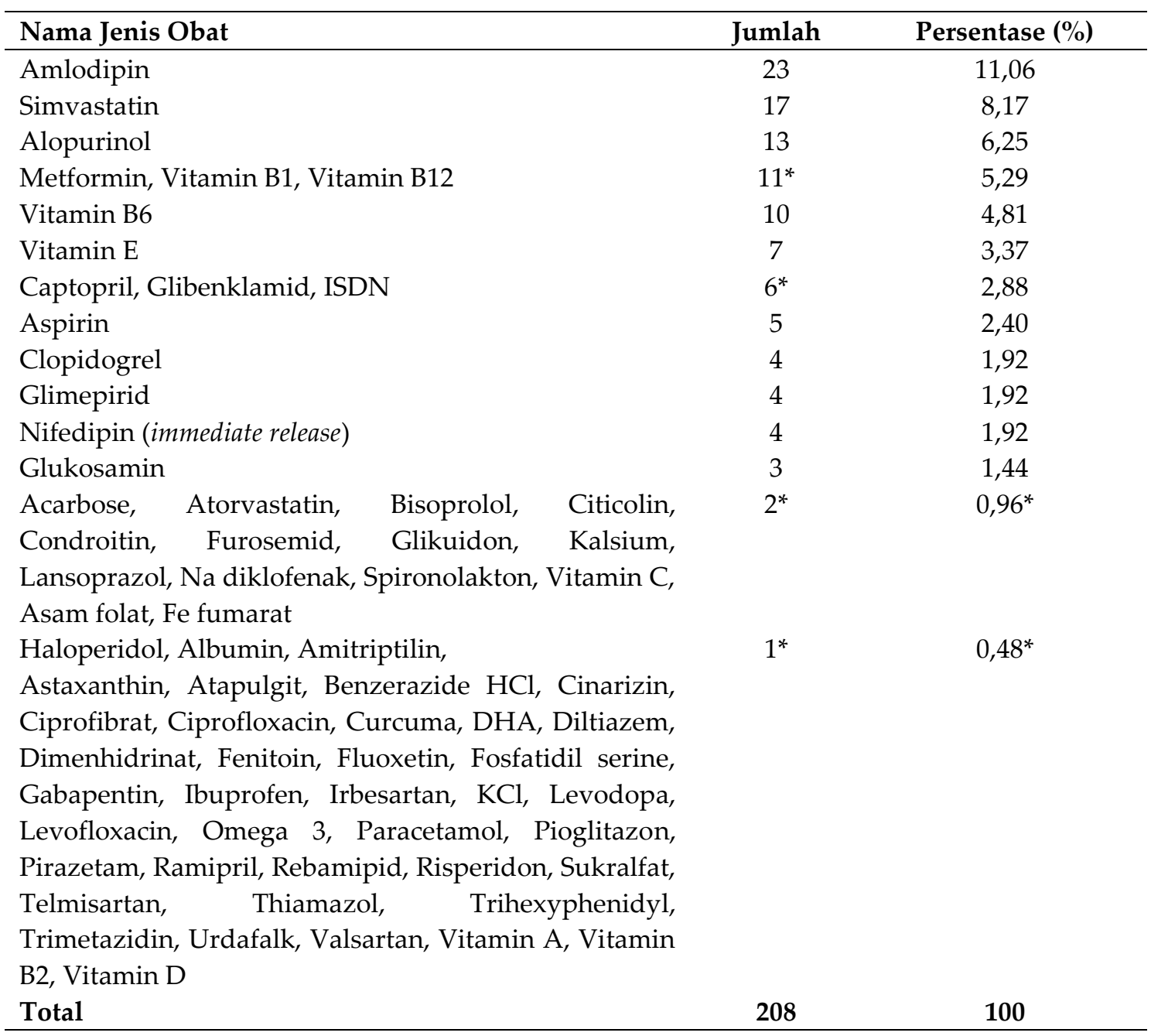

Keterangan: *Masing-masing jenis obat digunakan oleh lansia sejumlah angka yang dinyatakan; ISDN = Isosorbid dinitrat

sebagai upaya untuk mengidentifikasi efektivitas dan keamanan terapi.

Hasil uji korelasi menunjukkan tidak terdapat hubungan yang signifikan antara kerapuhan dan jumlah jenis MTO (correlation coefficient $=-0,027 ; \mathrm{P}=0,825)$. Jenis $\mathrm{MTO}$ terbanyak yang ditemukan pada penelitian ini adalah ketidaksesuaian dosis $(58,82 \%)$. Jenis MTO ini juga ditemukan pada penelitian yang dilakukan pada pasien panti jompo di Norwegia, selain masalah penggunaan obat yang tidak diperlukan dan perlu adanya pemantauan penggunaan obat. ${ }^{11}$ Tidak ditemukan penggunaan obat yang berinteraksi secara klinis pada lansia di penelitian ini. Detail informasi terkait MTO pada penelitian ini dapat dilihat pada Tabel V.

Ketidaktepatan pemberian dosis obat pada penelitian ini sebanyak 54 kasus yang terjadi pada 40 orang lansia dengan rincian sebagai berikut: 31 kasus overdose dan 23 kasus underdose. Kejadian overdose yang paling banyak (18 kasus; 33,33\%) terjadi dalam penelitian ini adalah penggunaan amlodipin dosis $5 \mathrm{mg}$ per hari untuk pasien lansia dengan hipertensi tanpa penyakit penyerta jantung. Dosis pada referensi acuan menyebutkan bahwa dosis amlodipin untuk lansia yang menderita hipertensi adalah 2,5 $\mathrm{mg} /$ hari. ${ }^{26}$ Secara teoritis, kelebihan dosis 
Tabel IV. Jenis Penyakit yang Diderita Lansia dalam Penelitian ini

\begin{tabular}{lcc}
\hline \multicolumn{1}{c}{ Jenis Penyakit } & Jumlah kasus & Persentase (\%) \\
\hline Hipertensi & 33 & 28,95 \\
Diabetes & 18 & 15,79 \\
Stroke, Asam urat & $14^{*}$ & $12,28^{*}$ \\
Kolesterol & 12 & 10,53 \\
Jantung & 9 & 7,89 \\
Kanker, Patah tulang & $2^{*}$ & $1,75^{*}$ \\
Oedema, Vertigo, Hipertiroid, Gangguan & $1^{*}$ & $0,88^{*}$ \\
penglihatan, Diare, Depresi, Batu Empedu, & & \\
Osteoartritis, Gangguan lambung, Infeksi kaki & & \\
Total & $\mathbf{1 1 4}$ & $\mathbf{1 0 0}$ \\
Rata-rata jenis penyakit per lansia & & $\mathbf{1 , 6 8}$ \\
\hline
\end{tabular}

Keterangan: *Masing-masing jenis penyakit diderita oleh lansia sejumlah angka yang dinyatakan

Tabel V. Hasil Identifikasi Masalah Terkait Penggunaan Obat

\begin{tabular}{lccc}
\hline \multicolumn{1}{c}{ Karakteristik } & Total (\%) & Panti Jompo Jenis A & Panti Jompo Jenis B \\
\hline $\begin{array}{l}\text { Interaksi obat } \\
\text { Ada interaksi* }\end{array}$ & $0(0,00 \%)$ & $0(0,00 \%)$ & $0(0,00 \%)$ \\
$\begin{array}{l}\text { Kesesuaian dosis } \\
\text { Dosis tidak tepat } \\
\text { (Underdose/Overdose) }\end{array}$ & $40(58,82 \%)$ & $23(50,00 \%)$ & $17(77,27 \%)$ \\
Ketidaktepatan pemilihan obat menurut kriteria STOPP \\
$\quad \begin{array}{c}\text { Tidak tepat } \\
\text { Ketidaktepatan pemilihan obat menurut Beers criteria } \\
\text { Tidak tepat } \\
13(19,12 \%)\end{array}$ \\
\hline
\end{tabular}

Keterangan: Panti Jompo Jenis $\mathrm{A}=$ terdapat petugas (perawat resmi berjumlah 4 orang khusus untuk mengurus pengobatan lansia). Jumlah panti jompo jenis $\mathrm{A}=1$ (satu); Panti Jompo Jenis $\mathrm{B}=$ tidak terdapat petugas khusus yang mengurus pengobatan lansia atau terdapat petugas tetapi bukan termasuk perawat resmi. Jumlah panti jompo jenis $\mathrm{B}=2$ (dua); ${ }^{*}=$ interaksi yang dimaksud adalah interaksi dengan level 1 dan 2.

amlodipin dapat menyebabkan hipotensi yang dapat meningkatkan risiko jatuh pada lansia. Namun, pada penelitian ini tidak dilakukan identifikasi terkait lama penggunaan amlodipin, hasil pengukuran tekanan darah lansia, dan riwayat kejadian jatuh pada lansia sehingga tidak diketahui secara pasti keamanan kelebihan dosis amlodipin tersebut. Dosis amlodipin tersebut perlu dikomunikasikan kepada tenaga kesehatan, khususnya dokter, terutama bila ingin memberikan terapi antihipertensi tambahan pada pasien. Jumlah kejadian underdose terbanyak, yakni terjadi pada 4 (empat) lansia terkait dengan penggunaan metformin $500 \mathrm{mg}$ yang hanya digunakan 1 kali/hari, sedangkan pada pustaka merekomendasikan metformin $500 \mathrm{mg}$ diminum 2 kali/hari dengan dosis maksimal $2.550 \mathrm{mg} /$ hari. ${ }^{26}$ Dua dari antara empat pasien tersebut menggunakan metformin tanpa dikombinasikan dengan antidiabetes oral lain. Penggunaan metformin dengan dosis 500mg 1kali/hari mungkin direkomendasi-kan pada pasien yang baru terdiagnosis diabetes mellitus dan belum memiliki riwayat penggunaan obat antidiabetes apapun. Pemberian dosis 500mg 1x/hari juga dapat dipertimbangkan untuk mencegah efek samping metformin yakni gangguan saluran 
cerna. ${ }^{37}$ Dosis tersebut dapat ditingkatkan apabila pasien tidak mengalami efek samping dan target gula darah belum tercapai. Namun pada penelitian ini, justifikasi tersebut tidak dapat dilakukan karena ketiadaan informasi terkait lama menderita DM, hasil pengukuran kadar gula darah pasien, dan riwayat keluhan pada saluran cerna. Pemantauan kadar darah sangat direkomendasikan untuk melihat apakah pemberian metformin dosis tunggal tersebut dapat mencapai target kadar gula darah yang diinginkan.

Pada penelitian ini ditemukan penggunaan obat yang seharusnya dihindari pada lansia. Analisis dengan menggunakan Beers criteria sebagai acuan menunjukkan terdapat 14 kasus penggunaan obat pada 13 orang lansia yang seharusnya dihindari. Sedangkan analisis dengan menggunakan kriteria STOPP sebagai acuan menemukan sebanyak 13 kasus penggunaan obat pada 13 orang lansia yang seharusnya dihindari (Tabel V). Penggunaan obat yang seharusnya dihindari tersebut dapat meningkatkan risiko lansia untuk mendapatkan ROTD dan perawatan di rumah sakit.14,15,38,39 Kejadian ROTD dan kebutuhan perawatan di rumah sakit dapat berdampak pada peningkatan biaya kesehatan yang perlu diantisipasi oleh pemerintah Indonesia pada periode implementasi Jaminan Kesehatan Nasional ini.

Jenis obat terbanyak yang sebaiknya dihindari penggunaannya, berdasarkan rekomendasi Beers criteria maupun STOPP criteria, adalah glibenklamid. Glibenklamid perlu dihindari penggunaannya pada lansia karena risiko hipoglikemia yang cukup tinggi dibandingkan dengan golongan antidiabetes oral yang lain. ${ }^{40}$ Selain berdampak pada peningkatan risiko terjadinya jatuh 33,34 , hipoglikemia pada lansia dapat menyebabkan penurunan kualitas hidup ${ }^{41}$ dan peningkatan risiko terjadinya serangan jantung, khususnya QT prolongation ${ }^{42}$. Oleh karena itu, penggunaan glibenklamid sebaiknya dihindari dan diganti dengan obat antidiabetes oral yang lain. Apabila dikehendaki penggunaan dari golongan sulfonilurea, baik sebagai terapi tunggal maupun kombinasi, penggunaan gliclazide khususnya dalam bentuk modified release $e^{43}$ atau jenis sulfonilurea lain dengan lama kerja obat yang pendek (short acting) seperti glipizide ${ }^{44}$ lebih disarankan.

Selain glibenklamid, menurut Beers criteria, nifedipin dalam bentuk sediaan immediate release merupakan jenis obat yang seharusnya dihindari penggunaannya pada lansia karena risiko hipotensi yang tinggi. Sebanyak empat (4) lansia dalam penelitian ini menggunakan nifedipin. Pedoman terapi terkait tata laksana terapi antihipertensi tidak secara eksplisit melarang penggunaan nifedipin pada kelompok lansia. ${ }^{29}$ Dalam pedoman terapi disebutkan bahwa dua golongan obat antihipertensi yang sebaiknya dihindari penggunaannya pada lansia adalah loop diuretics dan alpha-blockers karena dapat meningkatkan risiko jatuh pada lansia. ${ }^{29}$ Pada penelitian ini tidak dilakukan identifikasi terkait lama penggunaan nifedipin, hasil pengukuran tekanan darah lansia, dan riwayat kejadian jatuh pada lansia sehingga tidak diketahui secara pasti keamanan penggunaan nifedipin tersebut. Namun demikian, risiko hipotensi akibat pemberian antihipertensi pada lansia meningkat pada kondisi berikut: usia yang semakin tua, memiliki penyakit penyerta gagal jantung dan gangguan fungsi ginjal, lansia yang tidak aktif, kelemahan fisik. ${ }^{45}$ Oleh karena itu, penggantian nifedipin dengan obat lain perlu dipertimbangkan pada pasien lansia.

Penelitian yang dilakukan di beberapa panti jompo kota Surabaya ini memiliki beberapa keterbatasan. Pertama, hasil penelitian ini tidak dapat digeneralisasikan pada seluruh lansia yang berada di komunitas (community-dwelling elderly atau nonhospitalized elderly) dengan mempertimbangkan faktor yang telah dijelaskan pada beberapa paragraf di atas. Selain itu, hasil penelitian ini juga tidak dapat digeneralisasikan pada lansia dengan keterbatasan pendengaran, tidak bisa bicara, serta lansia yang menderita gangguan mental (termasuk pikun) karena kelompok lansia 
tersebut tidak dilibatkan dalam penelitian. Kedua, temuan MTO pada penelitian ini dapat lebih rendah (underestimate) dari prevalensi MTO pada lansia yang sesungguhnya. Hal tersebut terkait dengan terbatasnya jenis MTO yang diamati dalam penelitian ini dan tidak terdapatnya sumber informasi terdokumentasi yang memungkinkan dilakukannya analisis lebih komprehensif, misalnya: basis data atau catatan kesehatan di panti jompo. Informasi dalam penelitian ini didapatkan dari pasien atau petugas panti jompo yang mungkin memiliki keterbatasan untuk mengingat riwayat pengobatan dan riwayat sakit yang seharusnya dibutuhkan untuk mengidentifikasi berbagai jenis MTO.

\section{KESIMPULAN}

Sebanyak lebih dari $40 \%$ lansia di tiga panti jompo di kota Surabaya pada penelitian ini diklasifikasikan sebagai lansia yang rapuh (frail). Jenis MTO terbanyak yang ditemukan dalam penelitian ini adalah ketidaksesuaian dosis. Permasalahan terkait kerapuhan dan MTO yang ditemukan dalam penelitian ini menegaskan pentingnya dilakukan program kajian pengobatan (medication review) pada lansia secara periodik dan berkesinambungan. Adanya program tersebut diharapkan dapat mengidentifikasi MTO sedini mungkin sehingga mencegah terjadinya perburukan kondisi klinis pasien dan kebutuhan perawatan di rumah sakit.

\section{PENDANAAN}

Penelitian ini tidak didanai oleh sumber hibah manapun.

\section{KONFLIK KEPENTINGAN}

Peneliti menyatakan tidak terdapat konflik kepentingan apapun pada penelitian ini.

\section{DAFTAR PUSTAKA}

1. United Nations. World population ageing. 2017 [cited 2018 Agustus 1]. Available from: http://www.un.org/en/development/de sa/population/publication s/pdf/ageing/ WPA2017_Highlights.pdf.
2. The International Longevity Center Global Alliance. Global aging report: threats to longevity a call to action. 2009 [cited 2018 Agustus 1]. Available from:http://www.ilcalliance.org/images /uploads/publicationpdfs/0902_PUBLI CATIONS_Global_Aging_Report.pdf.

3. Kementerian Kesehatan Republik Indonesia. Analisis lansia di Indonesia. 2017. [cited 2018 Agustus 1]. Available from: http://www.pusdatin.kemkes. go.id/article/view/18012600001/analisislansia-di-indonesia-2017.html.

4. Badan Pusat Statistik Provinsi Jawa Timur. Persentase penduduk lansia hasil proyeksi penduduk menurut kabupaten/kota di Jawa Timur, 20102020. 2018 [cited 2018 Agustus 1]. Available from: https://jatim.bps.go.id/dynamictable /2018/02/06/328/persentase-penduduklansia-hasil-proyeksi-pendudukmenurut-kabupaten-kota-di-jawatimur-2010-2020.html.

5. Badan Pusat Statistik. Statistik penduduk lanjut usia. 2014 [cited 2018 Agustus 1]. Available from: https://www.bappenas.go.id/files/data/ Sumber_Daya_

Manusia_dan_Kebudayaan/Statistik\%2 0Penduduk\%20Lanjut\%20Usia\%20Ind onesia\%202014.pdf.

6. Badan Pusat Statistik Provinsi Jawa Timur. Penghuni Pantai Sosial Tresna Werdha (Lanjut Usia) menurut jenis kelamin, 2004-2016. 2017 [cited 2018 Agustus 1]. Available from: https://jatim.bps.go.id/statictable/ 2017/10/10/649 /penghuni-panti-sosialtresna-werdha-lanjut-usia-menurutjenis-kelamin-20042016.html.

7. Golchin N, Frank SH, Vince A, Isham L, Meropol SB. Polypharmacy in the elderly. J Res Pharm Pract. 2015 AprJun; 4(2): 85-88.

8. Nursing home-Silva C, Ramalho C, Luz I, Monteiro J, Fresco P. Drug-related problems in institutionalized, polymedicated elderly patients: 
opportunities for pharmacist intervention. Int J Clin Pharm. 2015;37:327-334.

9. Nursing home-Brulhart MI, Wermeille JP. Multidisciplinary medication review: evaluation of a pharmaceutical care model for nursing homes. Int J Clin Pharm. 2011;33(3):549-57.

10. Nursing home- Chen LL., Tangiisuran B., Shafie AA., Hassali MA. Evaluation of potentially inappropriate medications among older residents of Malaysian nursing homes. Int J Clin Pharm. 2012;34(4):596-603.

11. Nursing home-Fog AF., Kvalvaag G., Engedal K., Straand J. Drug-related problems and changes in drug utilization after medication reviews in nursing homes in Oslo, Norway. Scand J Prim Health Care. 2017;35(4):329-335.

12. Nyborg G., Straand J., Brekke M. Inappropriate prescribing for the elderly-a modern epidemic?. Eur J Clin Pharmacol. 2012;68(7):1085-94.

13. Tommelein E., Mehuys E., Petrovic M., Somers A., Colin P., Boussery K. Potentially inappropriate prescribing in community-dwelling older people across Europe: a systematic literature review. Eur J Clin Pharmacol. 2015;71(12):1415-27.

14. Wallace E., McDowell R., Bennett K., Fahey T., Smith SM. Impact of potentially inappropriate prescribing on adverse drug events, health related quality of life and emergency hospital attendance in older people attending general practice: a prospective cohort study. J Gerontol A Biol Sci Med Sci. 2017;72(2):271-277.

15. Cahir C., Bennett K., Teljeur C., Fahey T. Potentially inappropriate prescribing and adverse health outcomes in community dwelling older patients. $\mathrm{Br} \mathrm{J}$ Clin Pharmacol. 2014;77(1):201-10.

16. O'Mahony D., O'Sullivan D., Byrne S., O'Connor MN., Ryan C., Gallagher P. STOPP/START criteria for potentially inappropriate prescribing in older people: version 2. Age Ageing. 2015;44(2):213-218.

17. American Geriatrics Society 2012 Beers Criteria Update Expert Panel. American Geriatrics Society updated Beers Criteria for potentially inappropriate medication use in older adults. J Am Geriatr Soc. 2012;60:616-31

18. Cahir C., Moriarty F., Teljeur C., Fahey T., Bennett K. Potentially inappropriate prescribing and vulnerability and hospitalization in older communitydwelling patients. Ann Pharmacother. 2014;48(12):1546-54.

19. Cullinan S., O'Mahony D., O'Sullivan D, Byrne S. Use of a frailty index to identify potentially inappropriate prescribing and adverse drug reaction risks in older patients. Age Ageing. 2016;45(1):115-20.

20. Chen X., Mao G., Leng SX. Frailty syndrome: an overview. Clin Interv Aging. 2014;9:433-441.

21. Gilardi F., Capanna A., Ferraro M., Scarcella P., Marazzi MC., Palombi L., et al., Frailty screening and assessment tools: a review of characteristics and use in Public Health. Ann Ig. 2018;30(2):128139.

22. Pialoux T., Goyard J., Lesourd B. Screening tools for frailty in primary health care: a systematic review. Geriatr Gerontol Int. 2012;12(2):189-97.

23. van Houwelingen AH., den Elzen WP., le Cessie S., Blom JW., Gussekloo J. Consequences of interaction of functional, somatic, mental and social problems in community-dwelling older people. PLoS One. 2015;10(4):e0121013.

24. Verdoorn S., Verbeij A., Kwint HF., Blom J., Gussekloo J., Bouvy M. Which patients will have the highest risk for drug-related problems? A comparison between older patients with and without complex problems.

25. Hansten PD., Horn JR. Drug Interaction Analysis and Management. Misouri:Wolters Kluwer Health; 2013. 
26. Semla TP., Beizer JL., Higbee MD. Geriatric Dosage Handbook. 20th ed. Ohio: Lexicomp; 2015.

27. Siriwardhana DD., Hardoon S., Rait G., Weerasinghe MC., Walters KR. Prevalence of frailty and prefrailty among community-dwelling older adults in low-income and middleincome countries: a systematic review and meta-analysis. BMJ Open. 2018 Mar 1;8(3):e018195

28. Kaufmann CP., Stämpfli D., Hersberger KE., Lampert ML. Determination of risk factors for drug-related problems: a multidisciplinary triangulation process. BMJ Open. 2015;5:e006376.

29. Williams B., Mancia G., Spiering W., Rosei EA., Azizi M., Burnier M., et al., 2018 ESC/ESH Guidelines for the management of arterial hypertension. Eur Heart J. 2018;00:1-98.

30. American Diabetes Association. Older adults: standards of medical care in diabetes-2018. Diabetes Care. 2018;41(Suppl 1):S119-S125.

31. Finucane C., Kenny RA. Falls risk, orthostatic hypotension, and optimum blood pressure management: is it all in our heads?. Am J Hypertens. 2017;30(2):115-117.

32. Shaw BH., Claydon VE. The relationship between orthostatic hypotension and falling in older adults. Clin Auton Res. 2014;24:3-13.

33. Kachroo S., Kawabata H., Colilla S., Shi L., Zhao Y., Mukherjee J., et al., Association between hypoglycemia and fall-related events in type 2 diabetes mellitus: analysis of a U.S. commercial database. J Manag Care Spec Pharm. 2015;21(3):243-53.

34. Zhao Y., Kachroo S., Kawabata H., Colilla S., Mukherjee J., Fonseca V., et al., Association between hypoglycemia and fall-related fractures and health care utilization in older veterans with type 2 diabetes. Endocr Pract. 2016;22(2):196204.

35. Alekna V., Stukas R., TamulaitytèMorozovienėa I., Šurkienèa G., Tamulaitienėab M. Self-reported consequences and healthcare costs of falls among elderly women. Medicina. 2015;51:57-62.

36. Burns ER., Stevens JA., Lee R. The direct costs of fatal and non-fatal falls among older adults - United States. J Safety Res. 2016;58:99-103.

37. McCreight LJ., Bailey CJ., Pearson ER. Metformin and the gastrointestinal tract. Diabetologia. 2016;59:426-435

38. van der Stelt CA., Vermeulen Windsantvan den Tweel AM, Egberts AC., van den Bemt PM., Leendertse AJ., Hermens WA., et al., The association between potentially inappropriate prescribing and medication-related hospital admissions in older patients: a nested case control study. Drug Saf. 2016;39(1):79-87.

39. Kim GJ., Lee KH., Kim JH. South Korean geriatrics on Beers Criteria medications at risk of adverse drug events. PLoS One. 2018 Mar 15;13(3):e0191376.

40. Riddle MC. More reasons to say goodbye to glyburide. J Clin Endocrinol Metab. 2010;95(11):4867-4870.

41. Nicolucci A., Pintaudi B., Rossi MC, Messina R., Dotta F., Frontoni S., et al., The social burden of hypoglycemia in the elderly. Acta Diabetol. 2015;52(4):677-85.

42. Sircar M., Bhatia A., Munshi M. Review of hypoglycemia in the older adult: clinical implications and management. Can J Diabetes. 2016;40(1):66-72.

43. Clemens KK., McArthur E., Dixon SN., Fleet JL., Hramiak .I, Garg AX. The hypoglycemic risk of glyburide (glibenclamide) compared with 
Verlita Evelyn

modified-release gliclazide. Can J Diabetes. 2015;39(4):308-16.

44. Yakaryılmaz FD, Öztürk ZA. Treatment of type 2 diabetes mellitus in the elderly. World J Diabetes. 2017;8(6):278-285.

45. Zhu QO., Tan CS., Tan HL., Wong RG.,
Joshi CS., Cuttilan RA., et al., Orthostatic hypotension: prevalence and associated risk factors among the ambulatory elderly in an Asian population. Singapore Med J. 2016;57(8):444-51. 